\title{
School Names in Selected Districts in Southern Province of Zambia: A Critical Toponymies Perspective
}

\author{
Khama Hang'ombe ${ }^{1, ~ *}$, Emmanuel Chabata ${ }^{2}$, Zvinashe Mamvura ${ }^{2,3}$ \\ ${ }^{1}$ Department of African Languages and Literature, University of Zimbabwe, Harare, Zimbabwe \\ ${ }^{2}$ African Languages Research Institute, University of Zimbabwe, Harare, Zimbabwe \\ ${ }^{3}$ Department of African Languages, University of South Africa, Pretoria, South Africa
}

Email address:

hangombek@yahoo.com (K. Hang'ombe)

${ }^{*}$ Corresponding author

\section{To cite this article:}

Khama Hang'ombe, Emmanuel Chabata, Zvinashe Mamvura. School Names in Selected Districts in Southern Province of Zambia: A Critical Toponymies Perspective. International Journal of Language and Linguistics. Vol. 8, No. 3, 2020, pp. 88-99. doi: 10.11648/j.ijl1.20200803.11

Received: March 8, 2020; Accepted: April; 13, 2020; Published: May 12, 2020

\begin{abstract}
Studies have exposed place names as embodiments of the history, identity, culture, and language of their bestowers. Whilst this is true, some place naming practices reflect hegemonic tendencies that have not received adequate scholarly attention, especially in Zambia. This study examines school names in four districts in the Southern Province of Zambia and exposes the hegemonic slant inherent in place naming. The names examined in this study were collected from the Provincial Educational Offices. The names fall into two categories; government and private school names. These names were couched on Critical Toponymies Theory, a theory which politicises place naming and place names. The study found out that there is a toponymic hegemony in both categories of school names. The study argues that toponymic hegemony, as is shown in the study sample, is a manifestation of the dominance of the history, culture, world view, and identity or at least of the interests of the people who named the schools. It is concluded that place names, mundane as they may appear, are embroiled in the (re)production of unequal social power balance.
\end{abstract}

Keywords: Toponymic Hegemony, Southern Zambia, Critical Toponymies Theory

\section{Introduction}

This study examines school names in four districts in the Southern Province of Zambia; Kazungula, Livingstone, Namwala and Siavonga. The names studied showed that they are biased towards the aspirations and/or interests of their bestowers and, hence play a role in the (re)production of unequal social power balance. The biased nature of place names is an insignia denoting that at their core is hegemony of various kinds. This study brings out the biased nature of place names by exposing the toponymic hegemony which characterise the school names in the concerned districts. The informing philosophy in the study is that individually or collectively, people are never in equal positions to name places; not everyone has an opportunity to give names to places This suggests that names of any given geographical area are more likely to display some hegemony, culturally, economically, historically, and linguistically, among others.
The term hegemony is generally used to refer to the predominance of one thing over others. Hegemony is defined as "the power or dominance that one social group holds over others" [1]. In this sense, hegemony could be thought to be accompanied or motivated by differences between social classes within any given community whereby the more powerful group dominates and controls the weaker one (s). There are various types of hegemony, some of which include political, cultural, linguistic, and toponymic hegemony [ $\mathrm{cf} 2$, $3,4 \& 5$ ]. This study is concerned with toponymic hegemony which has a very close relationship with cultural hegemony (the predominance of one culture over others), political hegemony (the predominance of one political grouping/ideology over others), and linguistic hegemony (the predominance of one language over others) given that place names reflect culture, political interests, and the language of their namers. In this study, toponymic hegemony is defined as the dominion of one group of people over others' history, culture, language, identity, world view etc through place 
naming and place names. In fact, in toponymy, it would make sense to argue that there is a hyponymic relationship between toponymic hegemony and other kinds of hegemony such as cultural hegemony, linguistic hegemony, historic hegemony, and identity hegemony among many more, whereby toponymic hegemony is the hypernym while the rest are cohyponyms. This thinking is motivated by the fact that place names are carriers of history, language, culture, and identity and etcetera.

This study is inspired by many toponymic studies, some of which show that place names as historical records and, identity markers, vestiges of culture, guide to language distribution, and descriptors of the landscape that they refer to $[\mathrm{cf} 6,7,8,9,10 \& 11]$. A steadily growing body of literature in the study of place names also reveals that there is an economic dimension in some place names [cf 12]. These studies and many more, demonstrate that place names are not neutral designators in the sense that they reflect the history, culture, language, or identity of their bestowers.

\section{Zambia: A Geo-linguistic Overview}

This section provides an overview of Zambia's linguistic ecology. This is done in order to give the reader an appreciation of the language situation in the country and the region under study. The key source of the information provided in this section is from the 2010 Census of Population and Housing.

English is Zambia's official language. As such, in relation to the other languages spoken in Zambia, English has a higher status in the country. In Zambia, there are are eightythree local language spoken (15). However, they do not indicate the places in which each of the eighty-three languages is spoken in the country. On the other hand, there are seventy-two languages in the country, and seven of these are identified as major languages: Bemba, Kaonde, Lozi, Lunda, Luvale, Nyanja, and Tonga. It further indicates that out of the seventy-languages, Bemba and Nyanja are the widely spoken languages in the country [13]. These so-called major languages are sometimes referred to as national languages or Regional Official Languages (ROLs). The 'region' corresponds to political demarcations at provincial and/or district levels. Thus, there is a ROL in each province in Zambia [17].

Zambia is composed of ten provinces. These are Central, Copperbelt, Eastern, Luapula, Lusaka, Muchinga, Northern, North-Western, Western, and Southern provinces, Nyanja is the ROL for Central Province; Bemba for Copperbelt, Luapula, Muchinga and Northern Provinces; Nyanja for Eastern and Lusaka Province; Lozi for Western Province, Kaonde, Lunda and Luvale for North-Western Province; and Tonga for Southern Province and rural parts of Central Province [17].

The 2010 Census of Population and Housing shows that the Tonga people account for $74.4 \%$ of the total population of Southern Province, which stands at 1,338,649. The report shows that in addition to Tonga, the following languages are found in the province: Toka, Leya, Ila, Lozi, Nyanja, English and Bemba. The report further shows that Lozi is the main language in Western Province; Bemba is the main language in Northern, Luapula, and Copperbelt Provinces; while Nyanja is the main language in Eastern Province. However, it is highly probable that some of the speakers of these languages are actually native Tonga speakers who are bilingual. The few native speakers of Bemba, Nyanja and Lozi found in Southern Province, may not claim that their languages are domiciled in the province as the Ila, Leya and Toka speakers will do, guided by census report, whose languages are not known to be spoken in other provinces.

\section{Methods}

As earlier noted, the data for this study was collected from the Southern Province's Provincial Educational Offices in Choma, Zambia. The study used documentary analysis. This is a data collection method in qualitative research whereby the researcher interprets documents in order to elicit meaning from the data in the documents. Documentary analysis, the researcher examines and interprets the data to "elicit meaning, gain understanding, and develop empirical knowledge" [18]. The documents examined in this study are lists of school names for each of the four districts. The school names were grouped according to the characteristics they portrayed. Two groups were identified: English and Tonga school names. This made it easy for the study to address toponymic hegemony in the school names.

For data analysis, the study predominantly relied on the extensive toponymy approach. Extensive toponymy is based on corpora of place names that can be extracted from many sources [19]. In other words, this approach is concerned with big volumes of place names. In extensive toponymy, the researcher usually groups the names according to the characteristics they display. Intensive toponymy, on the other hand, is a kind of grass-root place names research whereby the researcher reaches out to a respondent for every name collected. Tent notes that this kind of place-names study is not the best when a researcher is dealing with many place names because, it would need more time and could be strenuous to the research budget. In extensive toponymy, the meaning of the names may not be explicitly touched upon. Since the collected names for this study were 354, it became prudent to predominantly use extensive toponymy because it would be difficult to find time and resources to reach to respondents for each school name. In this study, we use insights from both extensive and intensive toponymy.

\section{Critical Toponymies Theory}

This study uses Critical Toponymies Theory (CTT), a theory that views place naming as a contested process because different groups of people aspire to use place names to inscribe their lived experiences, worldview and aspirations in the social space through place names. Therefore, place names are not neutral intangible heritages. They are biased 
because they reflect the 'side of the story' of their bestowers. To appreciate the biased nature of place names, an appreciation that human beings have different aspirations, perceptions of the world, and cultural and linguistic identities is a prerequisite. This diversity so permeates place naming that if different individuals or groups of people were allowed to rename a given geographical area, chances are high that totally different kinds of names would be used to name the places, projecting totally different aspirations, perceptions and linguistic and cultural identities from that which was projected by the earlier names.

Literature on critical place names studies is pervaded by five major themes which combine to form CTT; place (name) commodification, banality and governmentality, symbolic resistance, scalar naming, and linguistic hegemony. This study utilises scalar naming and linguistic hegemony in its analysis.

With no specific reference to place names, scalar or scale has to do with size and position within a hierarchy [20]. Therefore, one can talk of scale in society while specifically referring to the position an individual or group of people occupy within a given social hierarchy. The position can be in relation to power, wealth and education. Any given scale has to be understood in relation to its interconnection and interaction with other scales [21]. As a result, social groups, governments and corporations tend to concurrently create diverse identities at different scalar levels using exactly the same elements. Scalar naming theme focuses on power dynamics arising from status and different positions that different things that are associated with place naming and place names, including people, occupy in society.

In place names, scale can be viewed from different perspectives such as the location of a place relative to key places and/or features, and the naming language for places [cf 22]. Regardless of the perspective, status takes the centre stage, whereby it is seen to have a strong bearing on the name selected for a place. Taking the factor of location as an example, politicians may have so much interest in places located in urban areas to a point that the names they select for such places are well thought-out in such a way that they leverage their interests. Equally, the rural folk may be so concerned with the names assigned to their rural places that the names they assign to their places become a narrative of their social, historical and cultural narratives. This explains the reason why place names are not neutral even when they appear so at face value. In addition, scale naming can be in relation to whether a place name or naming practice is viewed from a district, provincial, national or international perspective. The assumption is that depending on the scale (local scale, national or international scale) a place's significance may vary, thereby each scale determining the suitable name for the place.

In this study scale naming is used in relation to status accorded to the naming languages at national level. The school names are examined to identify whether there is a scale naming penchant towards any language. The assumption is that since the names are collected from the geographical areas where Tonga is the ROL, most of the school names will be in Tonga. Equally, it is expected that there are names in other local languages spoken in the areas where the names were collected. Against these expectations, the study examines the names to see whether there is a departure from this norm. Where such a departure is observed, the category of school names displaying it is identified and discussed accordingly.

The linguistic hegemony theme addresses the aspect of unequal distribution of place names among the languages spoken in a given region. Indigenous languages are disappearing at a faster rate due to the global domination of English such that about 3,500 languages are likely to be extinct by the year 2100 because some languages are absent in the toponymic landscape [23]. In other words, some ways of naming places, such as using one language to name places of any given geographical area where other languages are spoken, may lead to language death.

The present study's focus is toponymic hegemony, and linguistic hegemony is one of the forms of hegemony reflected in place names. Toponymic hegemony, in this study, is used to expose the extent to which place names can be used by one group of people to dominate other groups' culture, language and history and how such dominion is retrogressive to the well-being of those that are dominated.

\section{Findings and Discussion}

One of the findings of the study is that the examined school names show that there is toponymic hegemony in the districts where they were collected. The other finding is that private schools names are selected with an agenda of highstatus making for these schools. Although the second finding is closely related to toponymic hegemony, we deliberately separated it from toponymic hegemony in an attempt to foreground the biased nature of place names even when they may appear to be passive designators.

\subsection{Toponymic Hegemony and Its Implications}

The school names studied showed that there is a case of toponymic hegemony in government school names where Tonga names tend to dominate (there are more government schools named in Tonga than there are in other languages represented in the list of the examined school names). This implies that the Tonga people's culture, history, identity, and language dominate in the districts. A full list of the school names examined is presented in Table A1 which has 7 columns as follows: serial number, school name, language, district, and ward in which the school is found, a column showing whether the school is in urban or rural area and finally, a column indicating whether the school is a government or private school. Table 1 presents a summary of Table A1. 
Table 1. A summary of Table A1.

\begin{tabular}{|c|c|c|c|c|c|c|c|}
\hline \multirow{2}{*}{ Type of School } & \multicolumn{6}{|c|}{ Language } & \multirow{2}{*}{ Total } \\
\hline & Bemba & English & Ila & Lozi & Tonga & $\mathbf{X}$ & \\
\hline Government & 0 & 23 & 36 & 10 & 238 & 5 & 312 \\
\hline Private & 1 & 33 & 0 & 0 & 4 & 4 & 42 \\
\hline Total & 1 & 56 & 36 & 10 & 242 & 9 & 354 \\
\hline
\end{tabular}

Key.

$\mathrm{X}$ : The naming language is not known

As can be seen from Table 1, the languages of naming are Bemba, English, Ila, Lozi, and Tonga. It can also be noted that there are school names whose naming languages were not identified at the time of research. Out of the 354 school names, 242 are Tonga, 56 are English, 36 are Ila names, 10 are Lozi while only one school is named in the Bemba. The naming language (s) for the remaining 9 could not be established. From the examined corpus of school names, it is conspicuous that the Tonga school names dominate in each district. This can be attributed to the fact that, as stated already, Tonga is the ROL in the Southern Province where the districts from which the names were collected are found. In other words, Tonga is the dominant language in the districts.

Toponymic hegemony in the in the area studied is not only found in school names as it is also present in many other categories of place names in the districts. For example, Table 1 (items $109,198,124,118 / 122 \& 161 / 165$ ) indicates that the name of a school is also the name of a ward in some cases. It is suspected that an examination of the corpus of school names in the whole province would more vividly bring out this trend in the toponymic landscape of the province. A cursory survey of the list of school names in the province shows cases of toponymic replication, that is, cases where the name of a school in one district is also the name of schools in one or two other districts (see items 78/79 \& 15/16). This observation was corroborated by the study participants. The respondents also noted that in most cases, the name of a school is also the name given to other components of the built and natural environment places in the vicinity of the school such as dams, streams, hills, churches, villages, towns, streets, important buildings, clinics, agricultural extension areas, and grazing fields.

Many place-name studies such as have revealed that names are part of language, suggesting that toponymic hegemony whereby one language dominates the toponymic landscape of a given geographical area entails linguistic hegemony. On the relationship between naming and language, it can be noted that: "the disappearance of indigenous languages is accelerating dramatically under the weight of the global dominance of English and other major world languages. It is estimated that half of the world's 7,000 languages are expected to be extinct by 2100 , which will have a direct impact on the presence of competing ways of naming and hence knowing places" [23].

The hegemony is not only discussable where the so-called world languages are involved, but also between local languages as the case is with Tonga versus the other local languages in the Southern Province of Zambia. As such, the danger of language death noted by Rose-Redwood and Alderman due to the hegemony of the so-called world languages may also be cause for concern even in situations where there is hegemony between and among local languages. To have a glimpse into the hegemony of Tonga over the other languages in the light of the examined school names, let us have a closer look at Table 1: a cursory look at the school names in table shows that Ila is lucidly visible in Namwala district where the Ila people are found while Toka and Leya are completely absent in the toponymic landscape of Kazungula and Livingstone districts were the Leya and Toka people are found. Considering Rose-Redwood and Alderman's argument, this erratic visibility of the languages may be attributed to the dominance of the Tonga language in the region, which over time may result in the death of the dominated languages. As noted earlier in this study, the relationship between language and culture, history, and world view is so close that it is hardly possible to comprehensively talk about one without making reference to the other.

We have earlier noted that place names are historical records, identity markers, cultural bearers, and power emblems. Thus, an argument can be made that the toponymic hegemony noted in the study is a manifestation of the dominance of the Tonga people's culture, history, language, and identity in the studied districts. Since there are other ethnic groups that live in the districts in addition to the Tonga people, it can be argued further that the history, culture, language, and identity of these ethnic groups are dominated by that of the Tonga people. This status quo, however, is expected given that Tonga is the ROL of the province and districts under study and that, according to the census report, there are more Tonga people in the Southern Province. That notwithstanding, our view is that the history, culture, identity, and language of few people is as important as that of many people.

To better understand the effects of having one's culture, history and identity over-shadowed or dominated, there is need to know the importance of these social aspects to any group of people. The culture/tradition and history of any group of people is invaluably important to a point that its destabilisation becomes a ruthless assault on the humanhood of that group [26]. The term humanhood in this context is used to refer to anything that makes a group of people live a dignified life socially, economically, culturally and religiously, among others. Similalry, opines that "if a race [or group of people] has no history, if it has no worthwhile tradition... it stands in danger of being exterminated..." It 
follows then that the dominance of the Tonga people's culture, history and identity through the dominance of Tonga place names, has the potential to dehumanize, exterminate, and dislocate the Ila, Leya and Toka people socially, economically and religiously.

\subsection{Scale in School Naming}

The data studied also showed that there is a striking difference between private and government school names. Private school names are predominantly given in the English language while government school names are predominantly in Tonga. The list of school names examined in this study comprises 42 private schools. Out of the 42 private schools names, 33 are in English, 4 in Tonga while 1 is in Bemba. The language in which the remaining 4 are named was not identified. Looking at the combination of their morphemes, we can only speculate that some of them are bastardized forms of English names.

One of the plausible explanations, which was corroborated by three proprietors of private schools, for this state of affairs is that the goal of namers of private schools is to imbue high status on their schools. The rationale behind this philosophy is that English occupies a top notch on the language scale in Zambia because it is the official language of the country. For that reason, bestowing English names would be reflective of the high status that the schools should be viewed.

Three owners of private schools noted that the goal for most parents who send their children to private schools is so that they can speak and write good English. As such, one of the ways to attract them is to select an English name for the school. The respondents opined that a well thought out name; an English name, can easily pull parents to bring their children to the school. This is consistent with the observation that sometimes place names are selected on account of the status they command [cf 28]. When asked why it was important to imbue high status on private schools, the respondents argued that private schools are principally business entities; they are run on a profit-making basis. As a result, high status for these schools is invaluable if the schools are to compete favourably with government schools. A selection of place names driven by financial gain as the result is known as commodification in critical topomymies literature.

\section{Conclusion}

This study has used school names to argue that even seemingly banal place names are drawn in social power struggle, thereby making them poised toward the interests of their bestowers. It has also been shown that the dominance of Tonga government school names (re) produces, legitimizes and brings into mundane existence the Tonga people's worldview, history, and culture while denigrating that of the Ila, Toka, and Leya. This conclusion finds justification from the assertion that: "place naming represents a means of claiming the landscape, materially and symbolically, and using its power to privilege one's world view over another. [This is so because] toponyms are not simply evidence of history... but part of the ideologically driven process of visibly grounding the past into the present and framing these historical meanings as legitimate [28].

Thus, toponymic hegemony is an insignia of victory by the bestowers. On the other hand, this victory comes with a heavy price on those whose culture, identity, culture, and language is over-shadowed in the sense that it entails that the nucleus of their existence is threatened.

It has been shown in this study that government school names (which are predominantly named in Tonga) which appear innocent on account that they name schools in areas predominantly inhabited by the Tonga are not innocent; they perpetuate unequal social power balance in most of the social aspects that are projected in place names, especially that there are other ethnic groups that co-exist with the Tonga people in the concerned districts. On the other hand, the study shows how private school names are handy in leveraging the interests of those who own them. In other words, this study has contributed to a body of literature which argues that place names are key agents in social contestations. The outstanding feature of this study is that it exposes the non-prosaic temperament of place naming and place names using data drawn from both rural and urban areas.

The study recommends a study which examines all the school names in the Southern Province. Such a study may underscore toponymic hegemony and toponymic replication which may enhance the arguments advanced in this paper.

\section{Appendix}

Table A1. List of school names in Kazungula, Livingstone, Namwala, and Siavonga districts.

\begin{tabular}{llllll}
\hline S/N & School name & Language & District & Ward & Type \\
\hline 1 & Acacia International & English & Livingstone & Simonga & Uration \\
2 & Allison Future & English & Livingstone & Maramba & P. S \\
3 & Baambwe & Tonga & Namwala & Baambwe & Urban \\
4 & Bbakasa & Tonga & Siavonga & Nanyanga & Rural \\
5 & Bbugali & Tonga & Kazungula & Kauwe & Rural \\
6 & Bbuyu & Tonga & Namwala & Namakube & Rural \\
7 & Beautiful Beginnings & English & Livingstone & Shungu & G. S \\
8 & Bombwe & Tonga & Kazungula & Ngwezi & Urban \\
9 & Bright Day Christian & English & Livingstone & Libala & Rural \\
10 & Buiketo & Lozi & Kazungula & Musokotwane & Gr S \\
\hline
\end{tabular}




\begin{tabular}{|c|c|c|c|c|c|c|}
\hline $\mathbf{S} / \mathbf{N}$ & School name & Language & District & Ward & Location & Type \\
\hline 11 & Bunsanga & Tonga & Kazungula & Nyawa & Rural & G. S \\
\hline 12 & Busangu & Tonga & Namwala & Maala & Rural & G. S \\
\hline 13 & Busongo & Tonga & Livingstone & Dambwa & Urban & P. $\mathrm{S}$ \\
\hline 14 & Bwizu & Tonga & Namwala & Mbeza & Rural & G. S \\
\hline 15 & Chaanga & Tonga & Namwala & Namakube & Rural & G. S \\
\hline 16 & Chaanga & Tonga & Siavonga & Mulimya & Rural & G. S \\
\hline 17 & Chaba & Tonga & Livingstone & Mukuni & Rural & G. S \\
\hline 18 & Chabalanda & Tonga & Kazungula & Musokotwane & Rural & G. S \\
\hline 19 & Cheshire Homes & English & Livingstone & Akapelwa & Urban & G. S \\
\hline 20 & Chibiya & Tonga & Namwala & Nakamboma & Rural & G. S \\
\hline 21 & Chibote & Tonga & Namwala & Chitonga & Rural & G. S \\
\hline 22 & Chibule & Tonga & Namwala & Chitongo & Rural & G. $\mathrm{S}$ \\
\hline 23 & Chibunze & Tonga & Namwala & Baambwe & Rural & G. S \\
\hline 24 & Chibuyu & Tonga & Kazungula & Katapazi & Rural & G. $\mathrm{S}$ \\
\hline 25 & Chiili & Tonga & Kazungula & Chooma & Rural & G. S \\
\hline 26 & Chilaba & Tonga & Kazungula & Nyawa & Rural & G. S \\
\hline 27 & Chilala Riverside & Tonga & Namwala & Maala & Rural & G. S \\
\hline 28 & Chileleko & Tonga & Livingstone & Kasiya & Rural & G. S \\
\hline 29 & Chilumino & Tonga & Namwala & Kantengwa & Rural & G. S \\
\hline 30 & Chimilute & $\mathrm{X}$ & Livingstone & Mosi-Oa-Tunya & Urban & P. S \\
\hline 31 & Chininde & Tonga & Siavonga & Nanyanga & Rural & G. S \\
\hline 32 & Chinkonzya & Tonga & Kazungula & Simango & Rural & G. S \\
\hline 33 & Chisiwe & Tonga & Kazungula & Simango & Rural & G. $\mathrm{S}$ \\
\hline 34 & Chisumpule & Tonga & Namwala & Chitongo & Rural & G. S \\
\hline 35 & Chivuma & Tonga & Namwala & Chitongo & Rural & G. S \\
\hline 36 & Chizilika & Tonga & Siavonga & Mulimya & Rural & G. S \\
\hline 37 & Chooma & Tonga & Kazungula & Chooma & Rural & G. S \\
\hline 38 & Choonzo & Tonga & Kazungula & Moomba & Rural & G. S \\
\hline 39 & Chris Media & English & Namwala & Chitongo & Rural & G. $\mathrm{S}$ \\
\hline 40 & Christ The King & English & Livingstone & Mwalibonena & Urban & G. S \\
\hline 41 & Chuulu Chikunka & Tonga & Namwala & Chitongo & Rural & G. S \\
\hline 42 & Chuunga Namalazu & Tonga & Kazungula & Mukuni & Rural & G. $\mathrm{S}$ \\
\hline 43 & Dambilo & Tonga & Siavonga & Lusangazi & Rural & G. S \\
\hline 44 & Dambwa Christian & Tonga & Livingstone & Freedom & Urban & P. $\mathrm{S}$ \\
\hline 45 & Dambwa Secondary & Tonga & Livingstone & Dambwa & Urban & G. S \\
\hline 46 & David L/Stone Memorial & English & Livingstone & Akapelwa & Urban & P. S \\
\hline 47 & David Livingstone Secondary & English & Livingstone & Akapelwa & Urban & G. $\mathrm{S}$ \\
\hline 48 & Dibbwi & Tonga & Siavonga & Manchamvwa & Rural & G. $\mathrm{S}$ \\
\hline 49 & Donaleo & $\mathrm{X}$ & Kazungula & Mandia & Urban & P. S \\
\hline 50 & Dundumwezi & Tonga & Kazungula & Nguba & Rural & G. $\mathrm{S}$ \\
\hline 51 & Ebenezer Trust & English & Livingstone & Dambwa & Urban & P. $\mathrm{S}$ \\
\hline 52 & Ellain Britel & English & Livingstone & Mosi-Oa-Tunya & Urban & P. S \\
\hline 53 & Faith Christian Trust & English & Livingstone & Akapelwa & Urban & P. $\mathrm{S}$ \\
\hline 54 & Father Hugh Memorial & English & Livingstone & Kasiya & Urban & P. $\mathrm{S}$ \\
\hline 55 & Game & English & Siavonga & Kariba & Urban & G. S \\
\hline 56 & Gates Of Silver Lights & English & Livingstone & Akapelwa & Urban & P. S \\
\hline 57 & Global Samaritan & English & Kazungula & Musokotwane & Rural & P. S \\
\hline 57 & Great North Academy & English & Livingstone & Dr Mubitana & Urban & P. S \\
\hline 58 & Guta & Tonga & Kazungula & Nguba & Rural & G. S \\
\hline 59 & Hachibozu & Tonga & Siavonga & Mulimya & Rural & G. S \\
\hline 60 & Hakaloba & Tonga & Namwala & Ndema & Rural & G. S \\
\hline 61 & Hamajata & Tonga & Siavonga & Mulimya & Rural & G. S \\
\hline 62 & Highlands Creative & English & Livingstone & Dr Mubitana & Urban & P. $\mathrm{S}$ \\
\hline 63 & Highlands & English & Livingstone & Dr Mubitana & Urban & G. S \\
\hline 64 & Hillcrest & English & Livingstone & Mosi-Oa-Tunya & Urban & G. S \\
\hline 65 & Holycross & English & Livingstone & Akapelwa & Urban & G. S \\
\hline 66 & Ichila & Tonga & Namwala & Ndema & Rural & G. S \\
\hline 67 & Indeco & English & Livingstone & Simonga & Urban & G. S \\
\hline 68 & Inongwe Basic & Ila & Namwala & Ngabo & Rural & G. S \\
\hline 69 & Inongwe Central & Ila & Namwala & Ngabo & Rural & G. S \\
\hline 70 & Itapa & Ila & Namwala & Itapa & Rural & G. $\mathrm{S}$ \\
\hline 71 & James Siachitema & English & Kazungula & Nyawa & Rural & G. $\mathrm{S}$ \\
\hline 72 & Janda & Tonga & Kazungula & Chooma & Rural & G. S \\
\hline 73 & Johannymyburg & $\mathrm{X}$ & Siavonga & Nanyanga & Rural & G. $\mathrm{S}$ \\
\hline 74 & Kaambo & Tonga & Kazungula & Nyawa & Rural & G. S \\
\hline 75 & Kabanga & Tonga & Namwala & Mandondo & Rural & G. S \\
\hline 76 & Kabulamwanda & Tonga & Namwala & Kabulamwanda & Rural & G. S \\
\hline
\end{tabular}




\begin{tabular}{|c|c|c|c|c|c|c|}
\hline $\mathbf{S} / \mathbf{N}$ & School name & Language & District & Ward & Location & Type \\
\hline 77 & Kabulanjovu & Tonga & Kazungula & Ngwezi & Rural & G. S \\
\hline 78 & Kabuyu & Tonga & Siavonga & Sinadambwe & Rural & G. S \\
\hline 79 & Kabuyu & Tonga & Kazungula & Simango & Rural & G. S \\
\hline 80 & Kabwe & Tonga & Namwala & Moobola & Rural & G. $\mathrm{S}$ \\
\hline 81 & Kachabula & Tonga & Kazungula & Sikaunzwe & Rural & G. S \\
\hline 82 & Kalamba & Tonga & Kazungula & Moomba & Rural & G. S \\
\hline 83 & Kalundu & Tonga & Namwala & Namwala & Urban & G. S \\
\hline 84 & Kamatanda & Tonga & Kazungula & Mandia & Rural & G. $\mathrm{S}$ \\
\hline 85 & Kamwi & Tonga & Kazungula & Mukuni & Rural & G. S \\
\hline 86 & Kanchele & Tonga & Kazungula & Kanchele & Rural & G. S \\
\hline 87 & Kanimbwa & Tonga & Kazungula & Nyawa & Rural & G. S \\
\hline 88 & Kanono & Tonga & Kazungula & Kanchele & Rural & G. $\mathrm{S}$ \\
\hline 89 & Kantamba & Tonga & Kazungula & Nyawa & Rural & G. S \\
\hline 90 & Kantengwa & Tonga & Namwala & Kantengwa & Rural & G. $\mathrm{S}$ \\
\hline 91 & Kantumbi & Tonga & Kazungula & Kanchele & Rural & G. S \\
\hline 92 & Kapili & Tonga & Namwala & Namakube & Rural & G. S \\
\hline 93 & Kariba & $\mathrm{X}$ & Siavonga & Kariba & Urban & G. S \\
\hline 94 & Kasaya & Tonga & Kazungula & Sikaunzwe & Rural & G. S \\
\hline 95 & Kasenga & Tonga & Namwala & Kabulamwanda & Rural & G. S \\
\hline 96 & Kasensa & Tonga & Kazungula & Ngwezi & Rural & G. S \\
\hline 97 & Kasiya & Tonga & Livingstone & Kasiya & Rural & G. S \\
\hline 98 & Kasonkomwa & Tonga & Namwala & Itapa & Rural & G. S \\
\hline 99 & Katapazi & Tonga & Kazungula & Katapazi & Rural & G. $\mathrm{S}$ \\
\hline 100 & Katemwa & Tonga & Kazungula & Ngwezi & Rural & G. S \\
\hline 102 & Katombola & Tonga & Kazungula & Mandia & Rural & G. S \\
\hline 103 & Katondo & Tonga & Kazungula & Kauwe & Rural & G. S \\
\hline 104 & Katowa & Tonga & Namwala & Namakambo & Rural & G. S \\
\hline 105 & Katubya & Tonga & Kazungula & Ngwezi & Rural & G. S \\
\hline 106 & Katulumba & Tonga & Siavonga & Kariba & Rural & G. $\mathrm{S}$ \\
\hline 107 & Kaundu & Tonga & Namwala & Namakube & Rural & G. $\mathrm{S}$ \\
\hline 108 & Kaunga & Tonga & Kazungula & Kauwe & Rural & G. S \\
\hline 109 & Kauwe & Tonga & Kazungula & Kauwe & Rural & G. $\mathrm{S}$ \\
\hline 110 & Kawewa & Tonga & Kazungula & Sikaunzwe & Rural & G. S \\
\hline 111 & Kawila & Tonga & Siavonga & Lusangazi & Rural & G. S \\
\hline 112 & Kawilizhi & Ila & Namwala & Baambwe & Rural & G. S \\
\hline 113 & Kazungula Primary & Tonga & Kazungula & Mandia & Rural & G. S \\
\hline 114 & Kazungula Secondary & Tonga & Kazungula & Mandia & Rural & G. $\mathrm{S}$ \\
\hline 115 & Kazungula Riverview & Tonga & Kazungula & Malanda & Rural & G. $\mathrm{S}$ \\
\hline 116 & Kazunikalila & Ila & Namwala & Ndema & Rural & G. S \\
\hline 117 & Kentworth & English & Livingstone & Akapelwa & Urban & P. $\mathrm{S}$ \\
\hline 118 & Kids Ark Trust & English & Livingstone & Libala & Urban & P. $\mathrm{S}$ \\
\hline 119 & Kooma & Tonga & Kazungula & Sekute & Rural & G. S \\
\hline 120 & Koonje & Ila & Namwala & Namakube & Rural & G. S \\
\hline 121 & Kulishoma & Tonga & Siavonga & Kariba & Urban & P. $\mathrm{S}$ \\
\hline 122 & Libala & Lozi & Livingstone & Mosi-Oa-Tunya & Urban & G. S \\
\hline 123 & Libala & Lozi & Kazungula & Katapazi & Rural & G. S \\
\hline 124 & Libuyu Primary & Tonga & Livingstone & Libuyu & Urban & G. S \\
\hline 125 & Libuyu Secondary & Tonga & Livingstone & Libuyu & Urban & G. $\mathrm{S}$ \\
\hline 126 & Light Of Hope & English & Livingstone & & Urban & G. S \\
\hline 127 & Linda School & Tonga & Livingstone & Nansanzu & Urban & G. S \\
\hline 128 & Linda East Primary & Tonga & Livingstone & Nansanzu & Urban & G. S \\
\hline 129 & Linda Secondary & Tonga & Livingstone & Nansanzu & Urban & G. S \\
\hline 130 & Linda South & Tonga & Livingstone & Shungu & Urban & G. S \\
\hline 131 & Linda West & Tonga & Livingstone & Kariba & Urban & G. S \\
\hline 132 & Little Lambs & English & Livingstone & Akapelwa & Urban & P. $\mathrm{S}$ \\
\hline 133 & Little Teddy Ece & English & Livingstone & Simonga & Urban & P. $\mathrm{S}$ \\
\hline 134 & Livingstone & English & Livingstone & Freedom & Urban & G. S \\
\hline 135 & Local Cowboy Ece & English & Livingstone & Simonga & Urban & P. $\mathrm{S}$ \\
\hline 136 & Lubanga & Ila & Namwala & Lubanga & Urban & G. S \\
\hline 137 & Lubangabanga & Ila & Namwala & Kabulamwanda & Rural & G. S \\
\hline 138 & Lumbo & Tonga & Kazungula & Mandia & Rural & G. S \\
\hline 139 & Lunungu & Tonga & Kazungula & Ngwezi & Rural & G. $\mathrm{S}$ \\
\hline 140 & Lupani & Tonga & Kazungula & Sikaunzwe & Rural & G. S \\
\hline 141 & Luwe & Tonga & Kazungula & Chooma & Rural & G. S \\
\hline 142 & Maala & Ila & Namwala & Maala & Rural & G. S \\
\hline 143 & Maanumbwami & Tonga & Livingstone & Libuyu & Urban & G. S \\
\hline 144 & Mabwa & Tonga & Kazungula & Nyawa & Rural & G. S \\
\hline
\end{tabular}




\begin{tabular}{|c|c|c|c|c|c|c|}
\hline $\mathbf{S} / \mathbf{N}$ & School name & Language & District & Ward & Location & Type \\
\hline 145 & Mabwe & Tonga & Kazungula & Moomba & Rural & G. $S$ \\
\hline 146 & Maher Christian Academy & English & Livingstone & Akapelwa & Urban & P. S \\
\hline 147 & Mahululo & Tonga & Livingstone & Kasiya & Rural & G. S \\
\hline 148 & Makaba & Ila & Namwala & Chitonga & Rural & G. S \\
\hline 149 & Makkaba & Tonga & Siavonga & Sinadambwe & Rural & G. $S$ \\
\hline 150 & Makoli & Tonga & Kazungula & Katapazi & Rural & G. S \\
\hline 151 & Makotoolo & Tonga & Namwala & Chitongo & Rural & G. S \\
\hline 152 & Makumba & Tonga & Kazungula & Simango & Rural & G. S \\
\hline 153 & Makunka Primary & Tonga & Kazungula & Sekute & Rural & G. $\mathrm{S}$ \\
\hline 154 & Makunka Secondary & Tonga & Kazungula & Sekute & Rural & G. S \\
\hline 155 & Malembela & Ila & Namwala & Ngabo & Rural & G. S \\
\hline 156 & Malima & Tonga & Kazungula & Katapazi & Rural & G. S \\
\hline 157 & Malimba & Tonga & Kazungula & Nyawa & Rural & G. S \\
\hline 158 & Malombe & Tonga & Kazungula & Chooma River & Rural & G. S \\
\hline 159 & Malota & Tonga & Livingstone & Mulungushi & Urban & G. S \\
\hline 160 & Mambova & Tonga & Kazungula & Sikaunzwe & Rural & G. $\mathrm{S}$ \\
\hline 161 & Mamili Happy Horizon & English & Kazungula & Mandia & Urban & P. S \\
\hline 162 & Mamvu & Tonga & Namwala & Kabulamwanda & Rural & G. $\mathrm{S}$ \\
\hline 163 & Manchamvwa Inland & Tonga & Siavonga & Munyama & Rural & G. S \\
\hline 164 & Manchamvwa L. Shore & Tonga & Siavonga & Munyama & Rural & G. S \\
\hline 165 & Mandia & Lozi & Kazungula & Mukuni & Urban & G. S \\
\hline 166 & Mandondo & Ila & Namwala & Mandondo & Rural & G. S \\
\hline 167 & Mangwa & Tonga & Kazungula & Chooma & Rural & G. $\mathrm{S}$ \\
\hline 168 & Mangwele & Ila & Namwala & Chitonga & Rural & G. S \\
\hline 169 & Mankodi & Tonga & Kazungula & Kanchele & Rural & G. S \\
\hline 170 & Manono & Tonga & Kazungula & Sekute & Rural & G. S \\
\hline 171 & Mantolo & Ila & Namwala & Itapa & Rural & G. S \\
\hline 172 & Manyemunyemu & Tonga & Kazungula & Katapazi & Rural & G. S \\
\hline 173 & Mapampi & Tonga & Kazungula & Kauwe & Rural & G. S \\
\hline 174 & Maramba & $\mathrm{X}$ & Livingstone & Kasiya & Urban & G. S \\
\hline 175 & Maranatha & English & Livingstone & Lizuma & Urban & G. $\mathrm{S}$ \\
\hline 176 & Maria Assumpta & $\mathrm{X}$ & Livingstone & Libuyu & Urban & G. S \\
\hline 177 & Masompe & Ila & Namwala & Ndema & Rural & G. S \\
\hline 178 & Matengu & Tonga & Kazungula & Musokotwane & Rural & G. S \\
\hline 179 & Matuwa & Tonga & Siavonga & Simamba & Rural & G. S \\
\hline 180 & Maunga & Tonga & Kazungula & Musokotwane & Rural & G. S \\
\hline 181 & Mayobo & Tonga & Kazungula & Nguba & Rural & G. S \\
\hline 182 & Mazhiba & Ila & Namwala & Ndema & Rural & G. S \\
\hline 183 & Messiah & English & Livingstone & Zambezi & Urban & P. S \\
\hline 184 & Mitchel & English & Siavonga & Kariba & Rural & G. $\mathrm{S}$ \\
\hline 185 & Moobola & Tonga & Namwala & Moobola & Rural & G. $\mathrm{S}$ \\
\hline 186 & Moomba & Tonga & Kazungula & Moomba & Rural & G. S \\
\hline 187 & Moonga & Tonga & Siavonga & Lusangazi & Rural & G. S \\
\hline 188 & Mopani & English & Livingstone & Akapelwa & Urban & P. $\mathrm{S}$ \\
\hline 189 & Mother Eve & English & Livingstone & Lubuyu & Urban & P. S \\
\hline 190 & Mpango & Tonga & Siavonga & Simamba & Rural & G. $S$ \\
\hline 191 & Mubiana & Lozi & Kazungula & Katapazi & Rural & G. S \\
\hline 192 & Mubuyu & Tonga & Siavonga & Simamba & Rural & P. S \\
\hline 193 & Mubuyu Ovc & Tonga & Kazungula & Kauwe & Rural & G. S \\
\hline 194 & Muchambila & Tonga & Kazungula & Nyawa & Rural & G. S \\
\hline 195 & Muchila & Tonga & Namwala & Namakube & Rural & G. S \\
\hline 196 & Mujala & Tonga & Livingstone & Freedom & Urban & G. S \\
\hline 197 & Mukamusaba & Tonga & Livingstone & Freedom & Urban & G. S \\
\hline 198 & Mukuni & Tonga & Kazungula & Mukuni & Rural & G. S \\
\hline 199 & Mulala & Tonga & Namwala & Ndema & Rural & G. S \\
\hline 200 & Mulemi & Tonga & Kazungula & Mandia & Rural & G. $\mathrm{S}$ \\
\hline 201 & Mulindi & Tonga & Kazungula & Katapazi & Rural & G. S \\
\hline 202 & Mulwani & Tonga & Livingstone & Simonga & Urban & G. S \\
\hline 203 & Muntanga & Tonga & Siavonga & Mulimya & Rural & G. S \\
\hline 204 & Munyama & Tonga & Siavonga & Manchamvwa & Rural & G. S \\
\hline 205 & Musamumuyumu & Tonga & Kazungula & Kauwe & Rural & G. S \\
\hline 206 & Musokotwane & Tonga & Kazungula & Musokotwane & Rural & G. S \\
\hline 207 & Musokotwane & Tonga & Kazungula & Musokotwane & Rural & G. S \\
\hline 208 & Mutwanjili & Tonga & Kazungula & Katapazi & Rural & G. S \\
\hline 209 & Muyala & Tonga & Kazungula & Nguba & Rural & G. S \\
\hline 210 & Muyunda & Lozi & Kazungula & Nguba & Rural & G. S \\
\hline 211 & Mwaangwe & Ila & Namwala & Mandando & Rural & G. S \\
\hline
\end{tabular}




\begin{tabular}{|c|c|c|c|c|c|c|}
\hline $\mathbf{S} / \mathbf{N}$ & School name & Language & District & Ward & Location & Type \\
\hline 212 & Mwandi & Lozi & Livingstone & Freedom & Urban & G. S \\
\hline 213 & Mweemba & Tonga & Kazungula & Simango & Rural & G. $\mathrm{S}$ \\
\hline 214 & Nabutezi & Tonga & Siavonga & Simamba & Rural & G. S \\
\hline 215 & Nachilinda & Tonga & Kazungula & Sekute & Rural & G. S \\
\hline 216 & Nachuumba & Ila & Namwala & Chitongo & Rural & G. S \\
\hline 217 & Nakachenje & Ila & Namwala & Kabulamwanda & Rural & G. S \\
\hline 218 & Nakamboma & Ila & Namwala & Nakamboma & Rural & G. S \\
\hline 219 & Nakatindi & Lozi & Livingstone & Simonga & Urban & G. S \\
\hline 220 & Nakavundu & Ila & Namwala & Itapa & Rural & G. S \\
\hline 221 & Nalituwe & Lozi & Livingstone & Mosi-Oa-Tunya & Urban & G. S \\
\hline 222 & Nalombe & Tonga & Kazungula & Ngwezi & Rural & G. S \\
\hline 223 & Nalukwale & Ila & Namwala & Namakube & Rural & G. S \\
\hline 224 & Namaamba & Tonga & Kazungula & Nyawa & Rural & G. S \\
\hline 225 & Namakaka & Tonga & Namwala & Ndema & Rural & G. S \\
\hline 226 & Namakube-Musemu & Tonga & Namwala & Namakube & Rural & G. S \\
\hline 227 & Namankubaula & Ila & Namwala & Ngabo & Rural & G. $\mathrm{S}$ \\
\hline 228 & Namapande & Tonga & Kazungula & Sikaunzwe & Rural & G. S \\
\hline 229 & Namasanga & Ila & Namwala & Namakube & Rural & G. S \\
\hline 230 & Namasute & Tonga & Kazungula & Ngwezi & Rural & G. $\mathrm{S}$ \\
\hline 231 & Namatama & Lozi & Livingstone & Namatama & Urban & G. S \\
\hline 232 & Namayovu & Ila & Namwala & Namakube & Rural & G. S \\
\hline 233 & Naminwe & Ila & Namwala & Ngabo & Rural & G. S \\
\hline 234 & Namoomba & Tonga & Siavonga & Nanyanga & Rural & G. S \\
\hline 235 & Nampongo & Tonga & Kazungula & Simango & Rural & G. S \\
\hline 236 & Nampuyani & Tonga & Kazungula & Kauwe & Rural & G. S \\
\hline 237 & Namubanga & Tonga & Namwala & Namakube & Rural & G. S \\
\hline 238 & Namudimba & Tonga & Kazungula & Simango & Rural & G. $\mathrm{S}$ \\
\hline 239 & Namukaba & Tonga & Kazungula & Mandia & Rural & G. S \\
\hline 240 & Namumu & Tonga & Siavonga & Kariba & Rural & G. S \\
\hline 241 & Namusenga & Tonga & Namwala & Namakube & Rural & G. S \\
\hline 242 & Namusonde & Tonga & Namwala & Kabulamwanda & Rural & G. $\mathrm{S}$ \\
\hline 243 & Namwala Central & Tonga & Namwala & Namwal Central & Urban & G. S \\
\hline 244 & Namwala Secondary & Tonga & Namwala & Lubanga & Urban & G. S \\
\hline 245 & Namwala Primary & Tonga & Namwala & Lubanga & Urban & G. S \\
\hline 246 & Nansanzu & Tonga & Livingstone & Nansanzu & Urban & G. S \\
\hline 247 & Nansongwa & Tonga & Kazungula & Kauwe & Rural & G. S \\
\hline 248 & Nanyati & Tonga & Kazungula & Nyawa & Rural & G. S \\
\hline 249 & Nashongo & Tonga & Siavonga & Lusangazi & Rural & G. S \\
\hline 250 & Natebe Dam Primary & Tonga & Livingstone & Kasiya & Rural & G. S \\
\hline 251 & Natebe Primary & Tonga & Livingstone & Kasiya & Rural & G. S \\
\hline 252 & Nazibula & Tonga & Kazungula & Nguba & Rural & G. S \\
\hline 253 & Nchole & Tonga & Namwala & Kabulamwanda & Rural & G. S \\
\hline 254 & Ndeele & Tonga & Kazungula & Mukuni & Rural & G. S \\
\hline 255 & Ndema & Tonga & Namwala & Ndema & Rural & G. S \\
\hline 256 & Ngabo & Tonga & Namwala & Ngabo & Rural & G. S \\
\hline 257 & N'gandu & Tonga & Kazungula & Mukuni & Rural & G. S \\
\hline 258 & Nguba & Tonga & Kazungula & Chooma & Rural & G. S \\
\hline 259 & Ngweeze- Malo & Tonga & Kazungula & Sikaunzwe & Rural & G. S \\
\hline 260 & Ngwenya & Tonga & Livingstone & Namatama & Rural & G. S \\
\hline 261 & Niko Girls & Tonga & Namwala & Kabulamwanda & Rural & G. S \\
\hline 262 & Nkalikile & Tonga & Namwala & Kabulamwanda & Rural & G. S \\
\hline 263 & Nkomba & Tonga & Namwala & Moobola & Rural & G. S \\
\hline 264 & Nsanti & Tonga & Namwala & Kabulamwanda & Rural & G. S \\
\hline 265 & Nsongwe & Tonga & Kazungula & Mukuni & Rural & G. S \\
\hline 266 & Nyanzabili & Tonga & Livingstone & Libuyu & Urban & G. S \\
\hline 267 & Nyawa Primary & Tonga & Kazungula & Nyawa & Rural & G. S \\
\hline 268 & Nyawa Secondary & Tonga & Kazungula & Nyawa & Rural & G. S \\
\hline 269 & Nzwida & Tonga & Kazungula & Kanchele & Rural & G. S \\
\hline 270 & Oba Premia Trust & $X$ & Siavonga & Kariba & Urban & P. S \\
\hline 271 & Palmgrove & English & Livingstone & Shungu & Urban & P. S \\
\hline 272 & Parins & English & Livingstone & Akapelwa & Urban & P. S \\
\hline 273 & Queen's Gate & English & Siavonga & Kariba & Urban & P. S \\
\hline 274 & Saala & Tonga & Kazungula & Ngwezi & Rural & G. S \\
\hline 275 & Sekute & Tonga & Kazungula & Sekute & Rural & G. S \\
\hline 276 & Senkobo & Tonga & Kazungula & Musokotwane & Rural & G. S \\
\hline 277 & Shababwa & Ila & Namwala & Maala & Rural & G. S \\
\hline 278 & Shamukunchi & Ila & Namwala & Maala & Rural & G. S \\
\hline
\end{tabular}




\begin{tabular}{|c|c|c|c|c|c|c|}
\hline $\mathbf{S} / \mathbf{N}$ & School name & Language & District & Ward & Location & Type \\
\hline 279 & Shamutiki & Ila & Namwala & Namakube & Rural & G. S \\
\hline 280 & Shichaanda & Ila & Namwala & Mbeza & Rural & G. S \\
\hline 281 & Shimashikwe & Ila & Namwala & Itapa & Rural & G. S \\
\hline 282 & Shimatambo & Ila & Namwala & Moobola & Rural & G. S \\
\hline 283 & Shimayoba & Ila & Namwala & Maala & Rural & G. S \\
\hline 284 & Shimukopola & Ila & Namwala & Kantengwa & Rural & G. S \\
\hline 285 & Shimunyumbwe & Ila & Namwala & Chitongo & Rural & G. S \\
\hline 286 & Shokombwe & Ila & Namwala & Chitongo & Rural & G. S \\
\hline 287 & Shungu & Tonga & Livingstone & Maramba & Urban & G. S \\
\hline 288 & Siacabakubi & Tonga & Kazungula & Kanchele & Rural & G. S \\
\hline 289 & Siakalima & Tonga & Kazungula & Simango & Rural & G. S \\
\hline 290 & Siakalima & Tonga & Kazungula & Simango & Rural & G. S \\
\hline 291 & Siakasipa & Tonga & Kazungula & Musokotwane & Rural & G. S \\
\hline 292 & Siamasimbi & Tonga & Kazungula & Mukuni & Rural & G. S \\
\hline 293 & Siamatika & Tonga & Siavonga & Shimamba & Rural & G. S \\
\hline 294 & Siambaulwa & Tonga & Kazungula & Nyawa & Rural & G. S \\
\hline 295 & Siamulunga & Tonga & Kazungula & Simango & Rural & G. S \\
\hline 296 & Siamundele & Tonga & Kazungula & Nyawa & Rural & G. S \\
\hline 297 & Sianchelwa & Tonga & Kazungula & Nyawa & Rural & G. S \\
\hline 298 & Siandunda & Tonga & Kazungula & Mandia & Rural & G. S \\
\hline 299 & Siansina & Tonga & Kazungula & Musokotwane & Rural & G. S \\
\hline 300 & Sianyongo & Tonga & Kazungula & Nyawa & Rural & G. S \\
\hline 301 & Sianyoolo & Tonga & Siavonga & Sinadambwe & Rural & G. $\mathrm{S}$ \\
\hline 302 & Siavonga Primary & Tonga & Siavonga & Kariba & Urban & G. S \\
\hline 303 & Siavonga Secondary & Tonga & Siavonga & Kariba & Urban & G. S \\
\hline 304 & Sibbulo & Tonga & Kazungula & Sikaunzwe & Rural & G. S \\
\hline 305 & Sichaanda & Tonga & Namwala & Mbeza & Rural & G. S \\
\hline 306 & Sichibaka & Tonga & Kazungula & Nyawa & Rural & G. S \\
\hline 307 & Sichifulo & Tonga & Kazungula & Chooma & Rural & G. S \\
\hline 308 & Sihumbwa & Tonga & Kazungula & Kanchele & Rural & G. S \\
\hline 309 & Sikachapa & Tonga & Kazungula & Chooma & Rural & G. S \\
\hline 310 & Sikaunzwe & Tonga & Kazungula & Sikaunzwe & Rural & G. S \\
\hline 311 & Silelo & Tonga & Kazungula & Musokotwane & Rural & G. S \\
\hline 312 & Silongo & Tonga & Kazungula & Ngwezi & Rural & G. S \\
\hline 313 & Siluyasila & Tonga & Kazungula & Simango & Rural & G. S \\
\hline 314 & Simamba & Tonga & Siavonga & Simamba & Rural & G. $\mathrm{S}$ \\
\hline 315 & Simango & Tonga & Kazungula & Simango & Rural & G. S \\
\hline 326 & Simanje & Tonga & Namwala & Nakamboma & Rural & G. S \\
\hline 317 & Simatobolo & Tonga & Livingstone & Kasiya & Rural & G. S \\
\hline 318 & Simonga & Tonga & Livingstone & Simonga & Rural & G. S \\
\hline 319 & Simukali & Tonga & Kazungula & Simango & Rural & G. S \\
\hline 320 & Simukombo & Tonga & Kazungula & Sekute & Rural & G. S \\
\hline 321 & Simuumbwe & Tonga & Kazungula & Kauwe & Rural & G. S \\
\hline 322 & Sinadambwe & Tonga & Siavonga & Sinadambwe & Rural & G. S \\
\hline 323 & Sinde & Tonga & Kazungula & Musokotwane & Rural & G. S \\
\hline 324 & Singwamba & Tonga & Kazungula & Chooma & Rural & G. S \\
\hline 325 & Sinsimuka & Tonga & Kazungula & Kauwe & Rural & G. S \\
\hline 326 & Sitondo & Tonga & Kazungula & Moomba & Rural & G. S \\
\hline 327 & Sons Of Thunder & English & Kazungula & Kasiya & Rural & G. S \\
\hline 328 & Hermann Gmeiner & English & Livingstone & Dr Mubitana & Rural & P. S \\
\hline 329 & South Horizon & English & Livingstone & Akapelwa & Urban & P. S \\
\hline 330 & St Margret & English & Namwala & Moobola & Rural & G. S \\
\hline 331 & St Mary's & English & Livingstone & Libuyu & Urban & G. S \\
\hline 332 & St Peter's & English & Livingstone & Freedom & Urban & G. S \\
\hline 333 & St Raphael's & English & Livingstone & Namatama & Urban & G. S \\
\hline 334 & St. Kizito Ece & English & Livingstone & Simonga & Urban & P. S \\
\hline 335 & Syakalinda & Tonga & Siavonga & Mulimya & Rural & G. S \\
\hline 336 & Syamwiinga & Tonga & Siavonga & Mulimya & Rural & G. S \\
\hline 337 & Syanalumba & Tonga & Livingstone & Mwalibonena & Urban & G. S \\
\hline 338 & Taikila Ece & Bemba & Livingstone & Dambwa & Urban & P. S \\
\hline 339 & Tampwe & Tonga & Namwala & Namakube & Rural & G. S \\
\hline 340 & Terry Schwartz & English & Livingstone & Mubitana & Urban & G. S \\
\hline 341 & The Kings & English & Livingstone & Mubitana & Urban & P. S \\
\hline 342 & Thebe & English & Kazungula & Mandia & Urban & P. S \\
\hline 343 & Tongabezi Trust & $\mathrm{X}$ & Kazungula & Simonga & Rural & P. S \\
\hline 344 & Tusime & Tonga & Kazungula & Simango & Rural & G. S \\
\hline 345 & Twabuka & Tonga & Livingstone & Simonga & Rural & G. S \\
\hline
\end{tabular}




\begin{tabular}{|c|c|c|c|c|c|c|}
\hline $\mathbf{S} / \mathbf{N}$ & School name & Language & District & Ward & Location & Type \\
\hline 346 & Ungwe & Tonga & Kazungula & Ngwezi & Rural & G. S \\
\hline 347 & Vaala & Tonga & Kazungula & Ngwezi & Rural & G. S \\
\hline 348 & Victoria & English & Livingstone & Mosi-Oa-Tunya & Urban & P. S \\
\hline 349 & Vision & English & Livingstone & Freedom & Urban & P. S \\
\hline 350 & Wilson Adventist & English & Livingstone & Freedom & Urban & G. S \\
\hline 351 & Woodlands & English & Kazungula & Katapazi & Rural & G. S \\
\hline 352 & Zalu & Tonga & Kazungula & Nguba & Rural & G. S \\
\hline 354 & Zambezi Sawmills & English & Livingstone & Zambezi & Urban & G. S \\
\hline
\end{tabular}

Source: Provincial Education Office, Southern Province, Zambia.

Key.

G. S: Government school.

P. S: Private school.

$\mathrm{X}$ : Naming language not identified.

\section{References}

[1] Lull, James. A Cultural Studies Approach to Media: Theory. Colombia: Columbia University Press: 1995: 33.

[2] Gramsci, Antonio. Selections from the Prison Notebooks. Translated and edited by Quintin Hoare and Geoffrey Nowell Smith. New York: International Publishers: 1971.

[3] Lears, T. Jackson. The concept of cultural hegemony: Problems and possibilities. The American, Historical Review, 90 (1985): 567-593.

[4] Eriksen, H. Thomas. Linguistic Hegemony and Minority Resistance. Journal of Peace Research, 29.3 (1992): 313-332.

[5] Hui, H. L. Dennis. Geopolitics of Toponymic Inscription in Taiwan: Toponymic Hegemony, Politicking and Resistance. Geopolitics, No volume number, 2017: 1-28.

[6] Kovács, Eva. On the historical source value of toponyms: Toponyms as a source for the reconstruction of ethnic relations. Namenkundliche Informationen, 103/104 (2014): 480-490.

[7] Horsman, Stuart. The Politics of Toponyms in the Pamir Mountains. Area, 38.3 (2006): 279291.

[8] Saparov, Arseny. 2003. The Alteration of Place Names and Construction of National Identity in Soviet Armenia. Cahiers du Monde russe, 44.1 (2003): 179-198.

[9] Ainiala, Terhi. Place Names and Identities: The Uses of Names of Helsinki. Oslo Studies in Language, 4.2 (2012): 716.

[10] Wafer, Jim. Placenames as a guide to language distribution in the Upper Hunter, and the landnám problem in Australian toponomastics, in Clark, D. I, Hercus, L. and Kostanski, L. (eds) Indigenous and Minority Placenames. Australia: ANU Press, 2014: 212-224.

[11] Donada, T. Joan \& Reinoso, S. Alexis. Toponyms as 'landscape indicators'. Onomàstica: No Volume Number, 2014: 1987-2016.

[12] Light, Duncan \& Young, Craig. Toponymy as Commodities: Exploring the Economic Dimensions of Urban Place Names. International Journal of Urban and Regional Research, No volume number, 2014: 435-450.

[13] Central Statistical Office. 2010 Census of Population and Housing National Analytical Report. Lusaka, Zambia: 2012.

[14] Zambia. The Constitution of the Republic of Zambia Act 2. Lusaka: Government printers: 2016.

[15] Ohannessian, Sirarpi \& Kashoki, E. Mubanga. (eds). Language in Zambia. London: International African Institute, 1978.

[16] Marten, Lutz \& Kula, Nancy. Zambia: 'One Zambia, One Nation, Many Languages', in Simpson, A. (ed). Language and National Identity in Africa. New York: Oxford University Press, 2008: 291-313.

[17] Nkolola-Wakumelo, Mildred. Language and Good Governance in Zambia: The Situation and Considerations. Paper presented at National Workshop to Review the Broadcasting Policy in Zambian Languages and Languagein-Education Policy in Zambia in Lusaka, Zambia, 2007: 124.

[18] Bowen, A. Glenn. Document Analysis as a Qualitative Research Method. Qualitative Research Journal, 9.2 (2009): 27-40.

[19] Tent, Jan. Approaches to Research in Toponymy. Names, 63.2 (2015): 65-74.

[20] Hagen, Joshua. 2011. Theorizing scale in critical place-name studies. ACME: An International E-Journal for Critical Geographies, 10.1 (2011): 23-27.

[21] Howitt, Richard. Scale as relation: Musical metaphors of geographical scale. Area, 30.1 (1998): 4958.

[22] Medway, Dominic \& Warnaby, Garry \& Gillooly, Leah \& Millington, Steve. Scalar tensions in urban toponymic inscription: the corporate (re)naming of football stadia. Urban Geography, No volume number, 2018: 1-21.

[23] Rose-Redwood, Reuben \& Alderman, Derick. 2011. Critical Interventions in Political Toponymy. An International EJournal for Critical Geographies, 10.1 (2011): 5, 1-6.

[24] Mandana, Kolahdouz. An Ecolinguistic Approach Regarding Toponyms in Iran and India. Paper presented at Regional Dimensions of Social Development in India: Policy Perspectives conference in Februay, 2017: 1-13.

[25] Nash, Joshua. 2015. Placenames and Ecolinguistics: Some Considerations for Toponymists. AAA - Arbeiten aus Anglistik und Amerikanistik, 40, 2015: 66-71. 
[26] Thelwell, Michael. Duties, pleasures, and conflicts: Essays in struggle. Amherst: University of Massachusetts Press, 1987.

[27] Papanek. L. John. African Americans, voices of triumph: Leadership. Alexandria: Time-Life Books, 1994: 186.
[28] Alderman, H. Derick. 2008. Place, Naming, and the Interpretation of Cultural Landscapes, in Graham, B. and Howard. P. (eds) The Ashgate Research Companion to Heritage and Identity. City unknown: Ashgate, 2008: 195-213. 